\title{
Marine protected areas and area-based management in New Zealand
}

\section{Joanna Mossop ${ }^{1}$}

New Zealand's combined maritime zones are very large. The exclusive economic zone (EEZ) covers more than 4 million $\mathrm{km}^{2}$. In addition, New Zealand has rights to the resources of an additional 1.7 million $\mathrm{km}^{2}$ of continental shelf beyond the EEZ. Its maritime boundaries are settled, apart from one small area of the continental shelf beyond 200 nautical miles to the north. It is the home to a diverse range of marine biodiversity due to the size and length of the landmass and maritime zones. ${ }^{2}$ Although New Zealand does have some good measures in place to ensure protection of the marine environment, its implementation of marine protected areas and area-based management is relatively weak compared with other jurisdictions. ${ }^{3}$

Marine protected areas (MPAs) are related to area-based management (ABM), in that MPAs are one form of ABM. MPAs are commonly considered parts of the ocean in which particular activities may be restricted or prohibited in order to protect the marine environment. However, ABM goes much further, and refers to the process of managing the totality of human activities in marine areas to meet objectives including environmental protection and economic and social development.4

This paper sets out the legislative and administrative framework for marine planning and decision making in New Zealand, with a particular focus on marine protected areas. It will be seen that New Zealand's framework is somewhat disjointed and often inadequate. There are some successes, primarily related to the establishment of small protected areas. The special position of Māori as partners with the Crown under the Treaty of Waitangi (discussed below) has created opportunities and, in a few cases, has delayed government action.

\footnotetext{
${ }^{1}$ Associate Professor, Victoria University of Wellington, New Zealand. This is the Author's Accepted Manuscript. The final article was published in: (2020) 5 Asia-Pacific Journal of Ocean Law and Policy 169-185 https://brill.com/view/journals/apoc/5/1/article-p169_169.xml

${ }^{2}$ Dennis P Gordon et al, "Marine Biodiversity of Aotearoa New Zealand" (2010) 5 PLoS ONE e10905.

${ }^{3}$ Karen N Scott, "The Evolution of Marine Spatial Planning in New Zealand: Past, Present and Possible Future" (2016) 31 International Journal of Marine and Coastal Law 652-689.

4 IUCN, "Measures Such as Area-based Management Tools, Including Marine Protected Areas", http://www.un.org/depts/los/biodiversity/prepcom files/area based management tools.pdf
} 
Within the territorial sea, $17,430 \mathrm{~km}^{2}$ of water is protected by a marine reserve, while a further $4,685 \mathrm{~km}^{2}$ is covered by other forms of MPAs. ${ }^{5}$ This covers around $13 \%$ of the territorial sea. Beyond the territorial sea there are no no-take MPAs in the EEZ. However, in 2007 the fishing industry proposed that 17 areas be closed to bottom trawling and dredging, and these are now reflected in benthic protection areas and closed seamounts in the EEZ. This effectively closed one third of New Zealand waters to bottom trawling and dredging.

\section{Governance of New Zealand's maritime zones}

New Zealand is a democracy with a unicameral system for central government. There is no federal system, but there are provincial and local councils with some responsibility for managing marine areas, particularly those near shore. New Zealand's indigenous population is the Māori people. When New Zealand was settled by Europeans, a treaty was signed between Māori and the Crown, called the Treaty of Waitangi. The Treaty gave guarantees that Māori would retain ownership and sovereignty over their resources. However subsequent government action deprived Māori of rights and land. It was only in the 1970s that the New Zealand government began to make amends for historic wrongs. The government has also recognised the importance of partnership with Māori and recognition of customary practices and rights. Therefore, much of the policy and legislation in relation to oceans governance requires consultation with local Māori (tangata whenua).

New Zealand does not have an oceans policy to guide marine protection. One was proposed in the early 2000s, and a consultation process was begun. ${ }^{6}$ However, the process was derailed by a dispute between the government and Māori over the ownership of the foreshore and seabed. The government moved to legislate in a way that vested ownership in the foreshore and seabed in the Crown, although it retained an option for Māori to claim limited historical rights over the areas traditionally used. ${ }^{7}$ The dispute over this issue was

\footnotetext{
${ }^{5}$ Department of Conservation, 'Marine Protected Areas: Tier 1 statistic', https://www.doc.govt.nz/marineprotected-areas-tier-1-statistic.

${ }^{6}$ Joanna Vince and Marcus Haward, “New Zealand Oceans Governance: Calming Turbulent Waters?” (2009) 33 Marine Policy 412-418.

${ }^{7}$ See generally Richard Boast Foreshore and Seabed (LexisNexis, Wellington, 2005).
} 
politically extremely difficult and indirectly led to the shelving of the oceans policy agenda. ${ }^{8}$ As a result, New Zealand's legislation in relation to its maritime zones has developed on an ad hoc basis rather than reflecting a planned approach to area-based management. This has led to a complex, and confusing, overlap of legislation and agencies with different responsibilities.

Within the territorial sea the primary planning authority is devolved from central government and lies with Regional Councils under the Resource Management Act 1991 (RMA). ${ }^{9}$ The RMA applies on land and on sea out to the outer limit of the territorial sea and allows for decision making across the land and coastal environment for most activities apart from fishing and hydrocarbon exploration and exploitation. ${ }^{10}$ National guidance is provided by a New Zealand Coastal Policy Statement which the regional plans must conform to.

Fishing and hydrocarbon activities are governed by their own legislation, the Fisheries Act 1996 and the Crown Minerals Act 1991. These latter laws govern the sectoral activities across the range of maritime zones, not just the territorial sea. Marine protected areas are created by the Marine Reserves Act 1971, although it is also possible to establish marine sanctuaries under the Marine Mammals Protection Act 1978.

In the EEZ and on the continental shelf, there is no mechanism for integrated marine management. As in the territorial sea, fisheries and hydrocarbon exploitation are governed by different laws. The Exclusive Economic Zone and Continental Shelf (Environmental Effects) Act 2012 establishes a process for the management of activities beyond the territorial sea, although it does not apply to fishing. Activities are classified under the Act and Regulations as permitted, discretionary or prohibited. The Environmental Protection Authority (EPA) is responsible for considering applications for consent to undertake discretionary activities.

There are several different types of marine protection that can be created under New Zealand law. In the territorial sea, the key form of ecosystem protection is the

\footnotetext{
8 John Mansell “The Voyage Towards National Oceans Policy in New Zealand” (2004) 137 Maritime Studies 112.

9 See generally Trevor Daya-Winterbottom, "Protection of the Coastal and Marine Environment" in Peter Salmon and David Grinlinton (eds) Environmental Law in New Zealand (Thomson Reuters, Wellington, 2015) 701-788. See also appendix one for legislation that applies in the Territorial Sea.

${ }^{10}$ See Karen N Scott “Evolving MPA Management in New Zealand: Between Principle and Pragmatism" (2016) 47 Ocean Development and International Law 289-301, at 293.
} 
establishment of a marine reserve. Other protection can be afforded from certain activities. These include marine mammal sanctuaries and temporary closure of some areas of fishing under the Fisheries Act 1996. The government has also established benthic protection areas in the EEZ to prevent damage to the seabed environment. Finally, there are a number of specially-established areas subject to specific legal regimes. This paper will explore each of those in turn.

\section{$2 \quad$ Marine reserves}

\section{a) Establishment and legislation}

The Marine Reserves Act 1971 (MRA) is the legislative basis on which marine reserves can be established in New Zealand's internal waters or territorial sea. Although the public has access to marine reserves, fishing is not permitted. ${ }^{11}$ The MRA provides that the Act is intended to preserve marine reserves for the scientific study of marine life or to preserve underwater scenery, natural features or marine life that is unique, distinctive or beautiful. ${ }^{12}$ It is notable that, under the current legislation, the goal of conservation of marine biodiversity is not mentioned. ${ }^{13}$ An application for the establishment of a marine reserve can be made by a restricted number of entities or people including universities, organisations engaged in scientific study of marine life or natural history, local Māori and the Director General of the Department of Conservation (DOC). ${ }^{14}$ In practice, there is a process that allows the public to propose new reserves to DOC and for proposals to be developed through participatory processes. ${ }^{15}$ Notices of an intention to establish a marine reserve are published and, if objections are received, the Minister of Conservation must decide whether to uphold the objections. If the Minister is satisfied that declaring a marine reserve would interfere unduly with land-owners, navigation, commercial and recreational fishing or otherwise be contrary to the public interest, he or she must decline to establish

\footnotetext{
11 MRA, s 3(2) and 3(3). However, the Minister of Conservation authorised some recreational fishing in the past, for example in the Poor Knights Island Marine Reserve between 1981 and 1997. Carina Sim-Smith and Michelle Kelly, "A Literature Review on the Poor Knights Islands Marine Reserve" (Department of Conservation, 2009) at 46-47.

12 MRA, s 3(1).

13 Despite this, New Zealand has developed a plan to put in place MPAs to protect biodiversity. Department of Conservation, Marine Protected Areas: Policy and Implementation Plan (Wellington, 2005).

${ }^{14}$ MRA, s 5(1)

15 Kathryn Davies et al "The Evolution of Marine Protected Areas in Aotearoa New Zealand: Reflections on Participation and Process" (2018) 93 Marine Policy 113-127.
} 
the reserve. ${ }^{16}$ The recommendation to establish the reserve is also dependent on the agreement of Minsters of Transport and Fisheries. ${ }^{17}$ Due to these factors, the procedure is arguably "weighted in favour of existing rights to utilise fisheries resources". ${ }^{18}$

In a recent review of the legislation, it was argued that the process for establishment was inadequate, with poor consultation and consideration of proposals in isolation. ${ }^{19}$ The establishment of marine reserves can be contentious, with opposition from the fishing sector being a key obstacle in many cases. ${ }^{20}$ In addition, New Zealanders have a tradition of fishing, and imposing restrictions on fishing in any part of the ocean generally meets with resistance. It has been suggested that they consider recreational fishing as a "right". ${ }^{21}$ Local Māori populations can view marine reserves with suspicion if they consider the reserve may override customary rights and traditions. ${ }^{22}$ Although the MRA was ground-breaking when it was first introduced, it is now "inconsistent with modern MPA management principles."23

New Zealand has 44 marine reserves around its coast. ${ }^{24}$ Most are relatively small. The larger reserves are in the territorial sea of remote islands, such as those around the Kermadec Islands, Auckland Islands and Antipodes Islands. ${ }^{25}$ There is at least one marine reserve in each of the 14 identified biogeographic regions in New Zealand. ${ }^{26}$ Those reserves

\footnotetext{
16 MRA, s 5(6).

17 MRA, s 5(9).

${ }^{18}$ Randall Bess and Ramana Rallapudi "Spatial Conflicts in New Zealand Fisheries: The Rights of Fishers and Protection of the Marine Environment" (2007) 31 Marine Policy 719-729, at 725.

${ }^{19}$ Ministry for the Environment A New Marine Protected Areas Act: Consultation Document (MfE, 2016 ) at 12. Available at https://www.mfe.govt.nz/sites/default/files/media/Marine/mpa-consultation-doc.pdf. However it has been argued that public participation in planning of marine reserves has significantly improved over 30 years. Kathryn Davies et al, "The Evolution of Marine Protected Area Planning in Aotearoa New Zealand: Reflections on Participation and Process" (2018) 93 Marine Policy 113-127, at 122.

20 Simon A Banks and Greg A Skilleter, "Implementing Marine Reserve Networks: A Comparison of Approaches in New South Wales (Australia) and New Zealand" (2010) 34 Marine Policy 197-207, at 202; Bess and Rallapudi, above n 18, at 724.

${ }^{21}$ Nick Taylor and Brigid Buckenham, "Social Impacts of Marine Reserves in New Zealand" (Department of Conservation, 2003) at 32

22 Taylor and Buckenham, above n 21, at 39

${ }^{23}$ Karen N Scott, “Evolving MPA Management in New Zealand, above n 10, at 295-296.

${ }^{24}$ See appendix one for a summary of the area covered by each type of protection, and appendix four for a map showing the location of marine reserves.

25 https://www.doc.govt.nz/marinereserves. See appendix three.

${ }^{26}$ Kathryn Davies et al, "The Evolution of Marine Protected Area Planning in Aotearoa New Zealand: Reflections on Participation and Process" (2018) 93 Marine Policy 113-127, at 116.
} 
that have been established have been shown to be beneficial from socio-economic and ecological perspectives. ${ }^{27}$

In 2005 the New Zealand government launched an MPA Policy and Implementation Plan which was aimed at classifying marine habitats and ecosystems, creating management tools for MPAs, evaluating the representativeness of current protected areas, and developing a plan for establishing new MPAs. ${ }^{28}$ As a result of this work, the existing MPAs were classified according to the level of protection they afforded to biodiversity. Type 1 MPAs involved heavy protection including no-take rules. These were the marine reserves. Type 2 MPAs offered lesser protection to biodiversity including restrictions on the method of fishing, marine mammal sanctuaries and other activities. Other areas that had area based restrictions but did not significantly contribute to protection of biodiversity were not covered by the MPA Policy. ${ }^{29}$

One result of this work was a recognition that the existing framework for establishing MPAs was inadequate. In 2016 the government undertook a consultation process with a view to replacing the MRA with a new Act. One goal of the proposal was to ensure that MPAs could be established to form a representative and adaptable network. ${ }^{30}$ It was also aimed at improving the consultation process when new reserves are proposed and recognising more effectively the rights of Māori under the Treaty of Waitangi. The proposal was to establish four categories of marine protected areas. These were (1) marine reserves, which will afford the highest level of protection, (2) species-specific sanctuaries, (3) seabed reserves, and (4) recreational fishing parks.

A significant feature of the proposal was that it would only apply to the internal waters and territorial sea. The argument was that the territorial sea is where "the highest level of competition for access and resources currently exists" and "where the risks to marine biodiversity are greatest." 31 The consultation document argued that more was known about the territorial sea than the EEZ. Instead, the document anticipated that EEZ

\footnotetext{
${ }_{27}$ Mark Costello “Long Live Marine Reserves: A Review of Experiences and Benefits” (2014) 176 Biological Conservation 289-296.

${ }^{28}$ Department of Conservation and Ministry of Fisheries Marine Protected Areas: Policy and Implementation Plan (Wellington, 2005). Available at https://www.doc.govt.nz/Documents/conservation/marine-andcoastal/marine-protected-areas/mpa-policy-and-implementation-plan.pdf.

${ }^{29}$ See Policy and Implementation Plan, at 10-13 and appendix one.

30 Ministry for the Environment A New Marine Protected Areas Act: Consultation Document (MfE, 2016 ) at 15. Available at https://www.mfe.govt.nz/sites/default/files/media/Marine/mpa-consultation-doc.pdf.

$31 \mathrm{MfE}$, Consultation Document, at 16.
} 
MPAs could be introduced by way of special legislation. This aspect of the bill makes little sense. New Zealand's obligations in relation to marine biodiversity extend to all areas under its jurisdiction, and it seems short-sighted to restrict the possibility of MPAs beyond the territorial sea. Given that marine reserves in the EEZ was an option in earlier revisions of the MRA, it is likely that the fishing industry successfully lobbied the government to remove this option..$^{32}$ Their arguments would have been that the fishing industry had already supported the closure of some areas of the seabed to fishing (discussed below) and that special legislation could be used to implement any proposed sanctuaries. However, as will be discussed below, the certainty of getting legislation passed can be low in some cases.

No formal progress has been made on the new bill since the consultation document was created and the draft bill introduced. The government changed in 2017, and it seems to be low on the list of legislative priorities.

\section{b) Management and Enforcement}

Enforcement of marine reserve rules is the responsibility of the Department of Conservation. ${ }^{33}$ Relatively little information is available about how effective enforcement of marine reserves is in New Zealand. However, in a study published in 2003, Taylor and Buckenham found that poaching was common in the marine reserves they surveyed. It can be difficult for poorly-resourced DOC staff to detect poaching, and where offenders were spotted they were rarely prosecuted due to the difficulty or expense of obtaining sufficient evidence. ${ }^{34}$ Honorary rangers have been used to assist with enforcement, but their role can be challenging in the face of poaching. ${ }^{35}$ They recommended increased resources for DOC staff, including time, boats, radios and surveillance cameras and increased training for staff and honorary rangers. ${ }^{36}$ However, the authors also acknowledged that as the local population came to accept and support marine reserves, then locals sometimes selfenforced restrictions on taking fish. ${ }^{37}$

\footnotetext{
32 Bess and Rallapudi, above n 18, at 727.

${ }_{33}$ Ministry of Fisheries prior to 1987.

34 Taylor and Buckenham, above n 21 at 42 .

35 Sim-Smith and Kelly, above n 11, at 54.

36 Taylor and Buckenham, above n 21, at 47.

37 Taylor and Buckenham, above n 21, at 30.
} 
The government recently introduced changes to several pieces of legislation intended to give the Department of Conservation options beyond issuing a warning or a full-fledged prosecution. ${ }^{38}$ DOC officers are able to issue an infringement notice that carries a fine when given information about a minor offence. The MRA and the Marine Mammals Protection Act 1978 are also included in this system.

\section{$3 \quad$ Marine Mammal Sanctuaries}

New Zealand waters are home to approximately 43 species of cetaceans and nine species of seals. ${ }^{39}$ Harvesting and deliberately killing these species is prohibited in New Zealand maritime zones. However, dolphins and seals are often caught as by-catch in fishing nets. The Marine Mammals Protection Act 1978 (MMPA) allows for the establishment of marine mammal sanctuaries to protect species as well as the ability to impose fishing-related mortality limits (which mean that the regulated fishery must cease when a certain number of deaths of mammals as bycatch has been reached). ${ }^{40}$ Within the sanctuary, DOC can impose restrictions on activities. Although in most cases fishing and seismic surveys can be undertaken, there are restrictions about how they can be conducted. DOC has classified sanctuaries as type two MPAs, in that they offer less protection than marine reserves. ${ }^{41}$

New Zealand has eight marine mammal sanctuaries. Two large sanctuaries are the West Coast North Island and Banks Peninsula sanctuaries that are targeted in particular at limiting deaths of Hectors and Māui dolphins, which are at extremely low population levels. ${ }^{42}$ Restrictions in those sanctuaries include the prohibition of set net fishing, requiring seismic survey vessels to have marine mammal observers on board, and some prohibitions on seabed mining. It seems that such protections do lower the mortality of

\footnotetext{
${ }^{38}$ Conservation (Infringement System) Act 2018

${ }^{39}$ www.doc.govt.nz/nature/habitats/marine/other-marine-protection/. See also Gordon et al, above n 2, at 10.

${ }^{40}$ MMPA, ss 3F and 22.

${ }^{41}$ Marine Protected Areas: Classification, Protection Standard and Implementation Guidelines at 13.

42 SM Dawson and E Slooten "Conservation of Hector's Dolpins: The Case and Process which led to Establishment of the Banks Peninsula Marine Mammal Sanctuary” (1993) 3 Aquatic Conservation 207-221; KFD Hughey “An Evaluation of a Management Saga: The Banks Peninsula Marine Mammal Sanctuary, New Zealand” (2000) 58 Journal of Environmental Management 179-197.
} 
dolphins, but the level of by-catch in other parts of New Zealand waters means that the population is unlikely to recover unless further protection is put in place. ${ }^{43}$

\section{$4 \quad$ Benthic Protection Areas and Seamount Area Closures}

The largest areas of marine protection in New Zealand are designed to protect the seabed from the impacts of bottom fishing and dredging activities. New Zealand has 17 benthic protection areas (BPAs) and 18 seamount area closures (SACs) in its EEZ and continental shelf, covering 1.1 million $\mathrm{km}^{2}$, or approximately a third of the total EEZ. ${ }^{44}$ Within BPAs, bottom trawling and dredging and fishing within $100 \mathrm{~m}$ of the seabed is prohibited. In SACs, all forms of trawling are prohibited. The closed areas are intended to protect representative areas of relatively unfished benthic environment. ${ }^{45}$ The selection criteria for the BPAs were that they were to be large, relatively unfished, have simple boundaries and be broadly representative of the marine environment. ${ }^{46}$ Such areas are not classified as either Type 1 or Type 2 MPAs as they do not meet the biodiversity protection standard. ${ }^{47}$

Interestingly, the idea to close parts of the seabed originated with the fishing industry. ${ }^{48} \mathrm{New}$ Zealand manages its commercial fisheries using a quota management system. Under the Fisheries Act, the goal of ensuring sustainability, includes avoiding, remedying or mitigating any adverse effects of fishing on the benthic environment. ${ }^{49}$ The industry had hoped that the government would agree that the proposal met obligations under the Fisheries Act for the industry to avoid, remedy or mitigate any adverse effects of fishing on the benthic environment, and that no further closures would be necessary. ${ }^{50}$ The government did not agree to this. Changes to the original proposal were made on request by the Ministry of Fisheries, and also following consultation with the public.

Some criticism has been levelled at the BPAs. One problem identified is that $82 \%$ of the area protected by the BPAs is deeper than it is possible to trawl, meaning that there is a

\footnotetext{
43 KFD Hughey "An Evaluation of a Management Saga: The Banks Peninsula Marine Mammal Sanctuary, New Zealand" (2000) 58 Journal of Environmental Management 179-197.

44 See appendix two.

45 Jeremy Helson et al "Private Rights, Public Benefits: Industry-driven Seabed Protection" (2010) 34 Marine Policy 557-566, at 560.

${ }^{46}$ See further Helson at 560-561.

${ }^{47}$ https://www.doc.govt.nz/nature/habitats/marine/other-marine-protection/.

48 Helson et al, at 557.

49 Fisheries Act 1996, s 9.

${ }^{50}$ Helson et al, at 560 .
} 
question of representativeness of the areas protected, as well as minimal improvement on the footprint of the fishing industry. ${ }^{51}$ In addition, the BPA only applies to fisheries activities. In the Kermadec BPA, New Zealand has issued permits for mineral extraction in large parts of the BPA. ${ }^{52}$

In addition to these particular initiatives, it is possible for limited area-based restrictions to be imposed. These have historically been used for dealing with conflicts between recreational and commercial fishers. ${ }^{53}$

\section{$5 \quad$ Customary management areas}

The New Zealand government, as part of its obligations to Māori under the Treaty of Waitangi, has provided for some coastal areas to be subject to the control of local Māori. 54 Two types of protection can be granted over areas: mātaitai and taiāpure. 55

Mātaitai reserves are established to protect traditional fishing grounds in internal waters or coastal waters. Applications for mātaitai status can only be made by representatives of the tangata whenua in respect of traditional fishing grounds. ${ }^{56}$ Within a mātaitai, commercial fishing is prohibited, but recreational fishing can continue. The tangata whenua can also request the Minister of Fisheries to create bylaws that restrict or prohibit recreational fishing if they consider it necessary for sustainability of the fisheries. ${ }^{57}$

Other customary reserves are taiāpure-local fisheries. These areas recognise littoral coastal waters that have customarily been of special significance to tangata whenua as a source of food or for spiritual or cultural reasons. ${ }^{58}$ Applications to establish a taiāpurelocal fishery can be made by anyone, but the application must set out the reasons why the area is special and proposed controls. Consultation is required and an appeal against a decision by the Minister of Fisheries to establish a taiāpure-local fishery can be heard by a

\footnotetext{
51 Alison Rieser, Les Watling and John Guinotte, "Trawl Fisheries, Catch Shares and the Protection of Benthic Marine Ecosystems: Has Ownership Generated Incentives for Seafloor Stewardship?" (2013) 40 Marine Policy $75-83$, at 79 .

52 Ibid.

${ }^{53}$ Lucy Brake and Raewyn Peart Sustainable Seas: Managing the Marine Environment (Environmental Defence Society, 2015) at 124.

54 Treaty of Waitangi (Fisheries Claims) Settlement Act 1992, s 10. The local Māori community is referred to as Tangata Whenua (people of the land).

55 Bess and Rallapudi, above n 18, at 722.

56 Fisheries (Kaimoana Customary Fishing) Regulations 1998.

${ }^{57}$ Ministry of Fisheries Mãtaitai Reserve available at https://fs.fish.govt.nz/Doc/22261/Mataitai\%20reserve\%20handout\%20Nov\%2009.pdf.ashx.

58 Fisheries Act 1996, ss 174-185.
} 
tribunal. Due to this process, they are harder to establish than mātaitai. ${ }^{59}$ The Minister will appoint a management committee which can then make recommendations for the conservation and management of the marine environment.

The two areas are similar in purpose and effect. Taiāpure -local fisheries have been part of fisheries legislation since 1989.60 Mātaitai were introduced in 1992. It has been speculated that the key reasons for introducing the latter were that they are easier to establish and can be made in a slightly wider range of waters. ${ }^{61}$ As a result, the number of mātaitai reserves has increased sharply compared with the number of taiāpure reserves. ${ }^{62}$

Enforcement of mātaitai and taiāpure reserves rests with the Minister of Fisheries and fisheries officers. This is a distinction from marine reserves and marine mammal sanctuaries, which are enforced by DOC.

A final example of customary-based protection is the ability for temporary closures of areas to fishing or restriction on fishing methods in some places. Known as rāhui, these closures are made by the Minister responsible if he or she is satisfied that a method of fishing is having an adverse effect on the use and management practices of tangata whenua in the exercise of non-commercial fishing rights. ${ }^{63}$

\section{$6 \quad$ Specially-created protected areas}

The final category of area-based protection are those that have been specially created by legislation. The Hauraki Gulf Marine Park was established in 2000.64 It is perhaps the closest that New Zealand comes to true area-based management. A Hauraki Gulf Forum, consisting of representatives of government departments, local authorities and tangata whenua, is the body responsible for the integrated management of the area. ${ }^{65}$ Under the Hauraki Gulf Marine Park Act (HFMPA), the Forum has a role in developing a strategic plan, obtaining reports from stakeholders and monitoring the environment, and promoting the

\footnotetext{
59 RP Boast “Māori Fisheries 1986-1998: A Reflection" (1999) 30 Victoria University of Wellington Law Review 111-134, at 132.

${ }^{60}$ Māori Fisheries Act 1989.

${ }^{61}$ Boast, "Māori Fisheries", at 132; Bess and Rallapudi, at 722.

62 Janet Stephenson et al, "Biocultural Conservation of Marine Ecosystems: Examples from New Zealand and Canada" (2014) 13 Indian Journal of Traditional Knowledge 257-265, at 260.

${ }^{63}$ Fisheries Act 1996, s 186A.

${ }^{64}$ Hauraki Gulf Marine Park Act 2000

${ }^{65}$ Hauraki Gulf Forum Governing the Gulf: Giving effect to the Hauraki Gulf Marine Park Act through Policies and Plans (2009). Available at https://www.aucklandcouncil.govt.nz/about-auckland-council/how-aucklandcouncil-works/harbour-forums/docshaurakigulfguidanceseries/governing-gulf-giving-effect.pdf.
} 
integrated management of the area. ${ }^{66}$ However its powers are primarily related to recommending action to relevant parties. Government agencies and regional/local authorities are required to implement the priorities set out in the HFMPA.

The HFMPA requires decision makers to respect the interrelationship between the Gulf, its islands and catchments, and the ability of that interrelationship to sustain the lifesupporting capacity of the environment. ${ }^{67}$ The Act lists a number of objectives including ecological, social, cultural and economic goals. ${ }^{68}$ Although there is the possibility for tension between these interests, the requirement to sustain the life-supporting capacity of the marine environment means that the goal is not to simply allocate the Gulf's resources between competing users. ${ }^{69}$

Another special area is that established around the Kaikōura coast under legislation. ${ }^{70}$ The Kaikōura Marine Strategy utilises a variety of protection measures, including a marine reserve, two marine mammal sanctuaries, two taiāpure-local fisheries and three mātaitai reserves. ${ }^{71}$ An advisory committee, the Kaikōura Marine Guardians, provides recommendations to the Minister of Conservation and the Minister responsible for Fisheries, who must take the advice into account when making decisions for the Kaikōura Marine Area.

Such initiatives are only possible when political and community aspirations are in sync. An example of the difficulties that can arise when trying to establish special areas is the long-delayed Kermadec Ocean Sanctuary. In 2015 the Prime Minister announced the creation of a $620,000 \mathrm{~km}^{2}$ marine sanctuary (15\% of the EEZ) in the EEZ around the Kermadec Islands, to the north of New Zealand. There is already a marine reserve in place in the territorial sea around the islands, and a fisheries benthic protection area in the EEZ which prohibits dredging and bottom trawling. Creating a no-take area in the EEZ more generally was seen as a step towards New Zealand's Aichi Target to establish protected

\footnotetext{
66 HGMPA, s 17.

${ }^{67}$ HGMPA, 5 .

${ }^{68}$ HGMPA, s 8.

${ }^{69}$ Governing the Gulf, above n 65, at 33.

${ }^{70}$ Kaikōura (Te Tai ō Marokura) Marine Management Act 2014.

${ }^{71}$ See https://www.doc.govt.nz/nature/habitats/marine/kaikoura-te-tai-o-marokura-marine-managementarea/.
} 
areas in its maritime zones. ${ }^{72}$ Under the proposal, all fishing, hydrocarbon, and mining activities would be prohibited.

Unfortunately, the initiative was announced without appropriate consultation. The Regulatory Impact Statement that had been prepared had indicated that there was limited commercial fishing taking place in the Kermadec Region, which may have encouraged the perception that there would be few objections. ${ }^{73}$ However, the trust that held the quota for the region, Te Ohu Kaimoana, challenged the decision to establish the Sanctuary in court, arguing that it was against the principles of the Treaty of Waitangi and the terms of the Fisheries Claim Settlement that took place in $1992 .{ }^{74}$ They claimed that the establishment of the sanctuary would confiscate the quota that they hold for fishing in the Kermadec EEZ without compensation, and that insufficient consultation had taken place with Māori. The court proceedings were stayed pending the passage of the legislation through Parliament, ${ }^{75}$ but that never occurred. Negotiations have so far failed to resolve the disagreement. As the proposal was an initiative of the previous government, it remains to be seen whether the current government will proceed with the Sanctuary.

\section{$7 \quad$ Other protected areas}

Protected areas can be implemented under other legislation for particular purposes. One of these is the protection of submarine cables and pipelines. Protected areas can be established in any part of the internal waters, territorial sea and EEZ, and may prohibit a range of activities. ${ }^{76}$ In areas declared as cable protection zones (CPZ), anchoring and most types of fishing is prohibited. People who violate the rules are subject to prosecution by the Ministry of Transport. ${ }^{77}$ One example of a CPZ is the Cook Strait CPZ which is designed to

\footnotetext{
72 Cabinet paper, "Establishment of a Kermadec Ocean Sanctuary" 10 September 2015 <http://www.mfe.govt.nz/sites/default/files/media/Marine/Kermadec\%200cean\%20Sanctuary\%20Cabinet \%20Paper 0.pdf>; Joanna Mossop, "Law of the Sea and Fisheries" (2015) 13 NZYIL 267-271.

${ }^{73}$ http://www.mfe.govt.nz/sites/default/files/media/Legislation/RIS/RIS-for-kermadec-ocean-sanctuarybill 0 0.pdf>.

${ }^{74}$ For a discussion of the strength of the legal claims, see Ben France-Hudson, "The Kermadec/Rangitāhua Ocean Sanctuary: Expropriation-Free but a Breach of Good Faith" (2016) 12 Resource Management Theory and Practice 55-81.

75 Ibid, at 61.

76 Submarine Cables and Pipelines Act 1996, s 12.

77 Submarine Cables and Pipelines Act, ss 13-15. See also

https://www.transport.govt.nz/sea/protectingunderseacables/
} 
protect important power and telecommunication cables that run between the North and South Islands.

In some places, shipping is required to avoid sensitive marine areas. "Areas to be Avoided" are adopted pursuant to International Maritime Organization approval. New Zealand has two of these, around the Three Kings Islands and the Poor Knights Islands. Large vessels are required to navigate around those areas. ${ }^{78}$

\section{Comment}

Although New Zealand is considered by some to have a healthy environment, it must be said that the legislative and administrative structures in place to protect the marine environment are inadequate in light of modern principles of MPA design and area-based management more generally. The marine environment is subject to a disjointed regime of sectorally-based legislation with limited ability to achieve integration between different activities. The legislation that provides for the most highly protected marine reserves is out-dated and it is not clear when, or even whether, the Marine Reserves Bill will be passed into legislation. It has been suggested that the plethora of different forms of protection can

give rise to a feeling of competition for space among users who may resent being shut out of certain areas. ${ }^{79}$

There is little about New Zealand's approach to marine protection that could be said to be representative of good practice ${ }^{80}$ Probably the most interesting aspects are the areas where the government has provided for local representatives to try to give a more integrated view of the management of marine areas in the Hauraki Gulf and Kāikoura. ${ }^{81}$ Even in those cases, the representative groups have limited authority beyond issuing reports and recommendations.

A glance at a map showing New Zealand's protected areas gives the impression that a considerable amount of the marine environment is protected. However, the majority are benthic protection areas that were created for areas that had little existing trawling and so

\footnotetext{
78 Maritime New Zealand, “Marine Protection Rules: Part 190”, https://www.maritimenz.govt.nz/rules/part190/Part190-marine-protection-rule.pdf

79 Bess and Rallapudi, above n 18, at 725.

80 See Michael McGinnis “Living Up to the Brand: Greening Aotearoa's Marine Policy” (2012) 8 Policy

Quarterly 17-28.

81 Scott, "Evolution of Marine Spatial Planning in New Zealand", above n 3, at 686.
} 
the added protection is minimal. Fishing is still permitted in the area above the seafloor. ${ }^{82}$ Currently the government is not expressing an intention to make significant progress on this matter, which probably reflects a relative lack of understanding about the marine environment among the public generally. ${ }^{83}$ Without a comprehensive approach to spatial management in the marine environment it is likely that the goal of creating truly representative protection is a long way off.

\footnotetext{
82 This is consistent with international practice, in which $94 \%$ of marine protected areas allow fishing. Mark J Costello and Bill Ballentine "Marine Biodiversity Conservation Should Focus on No-take Marine Reserves" (2015) 30 Trends in Ecology \& Evolution 507-509.

83 Tyler D Eddy “One Hundred-fold Difference between Perceived and Actual Levels of Marine Protection in New Zealand" (2014) 46 Marine Policy 61-67.
} 
Appendix One: Areas covered by marine protection tools ${ }^{84}$

\begin{tabular}{|c|c|c|c|c|}
\hline Type & NZ MPA Category & IUCN category & Number & Total surface $\left(\mathrm{km}^{2}\right)$ \\
\hline Marine reserve & Type $1 \mathrm{MPA}$ & Ia & 44 & 17,700 \\
\hline Fisheries closure & Type 2 MPA & & 7 & 2,625 \\
\hline Submarine cable closure & Type 2 MPA & & 8 & 1,577 \\
\hline Fiordland Marine Area & Type 2 MPA & & 1 & 380 \\
\hline Marine Park & Type 2 MPA & & 2 & 22 \\
\hline Benthic protection area & - & VI & 17 & $1,151,204$ \\
\hline Seamount closure & - & VI & 17 & 108,128 \\
\hline Marine mammal sanctuary & - & - & 8 & 28,128 \\
\hline
\end{tabular}

${ }^{84}$ Source: Department of Conservation 
Appendix Two: Existing Marine Management Legislation in New Zealand's Territorial Sea ${ }^{85}$

\begin{tabular}{|c|c|c|c|}
\hline Management area & Legislation & Spatial Area & Managing Authorities \\
\hline \multirow[t]{2}{*}{$\begin{array}{l}\text { Resource } \\
\text { management }\end{array}$} & $\begin{array}{l}\text { Resource Management } \\
\text { Act }\end{array}$ & $\begin{array}{l}\text { Catchments, islands, } \\
\text { territorial sea }\end{array}$ & $\begin{array}{l}\text { Minister of Conservation } \\
\text { Regional councils } \\
\text { Territorial authorities }\end{array}$ \\
\hline & $\begin{array}{l}\text { EEZ (Environmental } \\
\text { Effects) Act }\end{array}$ & EEZ and continental shelf & $\begin{array}{l}\text { Minister for the Environment } \\
\text { Environmental Protection Authority }\end{array}$ \\
\hline Fisheries & $\begin{array}{l}\text { Fisheries Act } \\
\text { Treaty of Waitangi } \\
\text { (Fisheries Claims) } \\
\text { Settlement Act } \\
\text { Māori Fisheries Act }\end{array}$ & $\begin{array}{l}\text { Freshwater, territorial sea } \\
\text { and EEZ }\end{array}$ & $\begin{array}{l}\text { Minister for Primary Industries } \\
\text { Supported by Ministry for Primary } \\
\text { Industries (MPI) }\end{array}$ \\
\hline
\end{tabular}

${ }^{85}$ Adapted from Brake and Peart. 


\begin{tabular}{|c|c|c|c|}
\hline Mining & $\begin{array}{l}\text { Crown Minerals Act } \\
\text { Continental Shelf Act }\end{array}$ & $\begin{array}{l}\text { Land, territorial sea, EEZ } \\
\text { and continental shelf }\end{array}$ & $\begin{array}{l}\text { Minister of Energy and Resources } \\
\text { Supported by Ministry of Business, } \\
\text { Innovation and Employment through NZ } \\
\text { Petroleum and Minerals }\end{array}$ \\
\hline Shipping & Maritime Transport Act & & \\
\hline Marine pollution & Maritime Transport Act & Territorial sea and EEZ & Maritime New Zealand \\
\hline Biosecurity & Biosecurity Act & Land and territorial sea & Minister for Primary Industry and MPI \\
\hline Marine protection & $\begin{array}{l}\text { Marine Reserves Act } \\
\text { Marine Mammals } \\
\text { Protection Act } \\
\text { Wildlife Act }\end{array}$ & $\begin{array}{l}\text { Territorial sea } \\
\text { Territorial sea and EEZ } \\
\text { (not continental shelf) } \\
\text { Land, territorial sea and } \\
\text { EEZ (not continental shelf) }\end{array}$ & $\begin{array}{l}\text { Minister of Conservation and } \\
\text { Department of Conservation (DOC) }\end{array}$ \\
\hline
\end{tabular}

\begin{tabular}{|c|c|}
\hline ISSUE & RELEVANT LEGISLATION \\
\hline Effects management (excluding fisheries) & Resource Management Act 1991 \\
\hline
\end{tabular}




\begin{tabular}{|c|c|}
\hline ISSUE & RELEVANT LEGISLATION \\
\hline Fisheries management (including effects) & Fisheries Act 1996 \\
\hline Marine reserves & Marine Reserves Act 1971 \\
\hline $\begin{array}{l}\text { Species protection } \\
\text { (including seabirds, some fish and corals) }\end{array}$ & $\begin{array}{l}\text { Wildlife Act } 1953 \text { (not continental shelf) } \\
\text { Marine Mammals Protection Act } 1978 \text { (not continental } \\
\text { shelf) }\end{array}$ \\
\hline Biological security & Biosecurity Act 1993 \\
\hline Shipping & Maritime Transport Act 1994 \\
\hline Access to minerals & Crown Minerals Act 1991 \\
\hline Historic heritage & Historic Places Act 1993 \\
\hline Seabed rights & Marine and Coastal Area (Takutai Moana) Act 2011 \\
\hline Treaty settlements & Various Acts \\
\hline $\begin{array}{l}\text { Special legislation resulting from community- or stakeholder-based } \\
\text { initiatives }\end{array}$ & $\begin{array}{l}\text { Kaikōura (Te Tai o Marokura) Marine Management Act } \\
2014 \\
\text { Subantarctic Islands Marine Reserves Act } 2014 \\
\text { Fiordland (Te Moana o Atawhenua) Marine Management } \\
\text { Act } 2005 \\
\text { Sugar Loaf Islands Marine Protected Area Act } 1991\end{array}$ \\
\hline
\end{tabular}


Source: MfE, A New Marine Protected Areas Act: Consultation Document (2016) 
